بررسى اثر محافظتى عصاره هيدروالكلى برتى به (Cydonia oblonga) بر تير

تغييرات ساختمانى بافت بيضه القاء شده توسط ميدر مونوسيديم

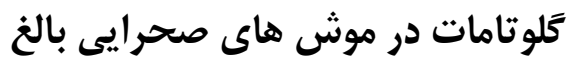

زيلا حميدى'، داوود كيانى فرد"، غلامرضا وفايى سياح'، رضا حضرتى'

ا) كروه علوم باياه، دانشكده داميزشكى، دانشكاه تبريز، تبريز، ايرانغ

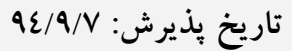

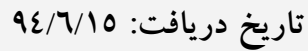

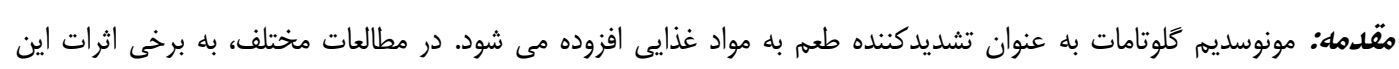

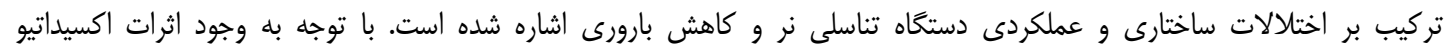

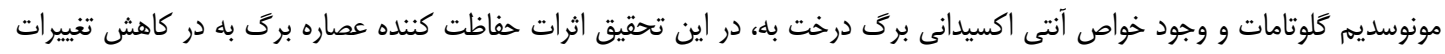

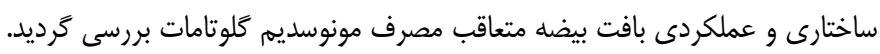

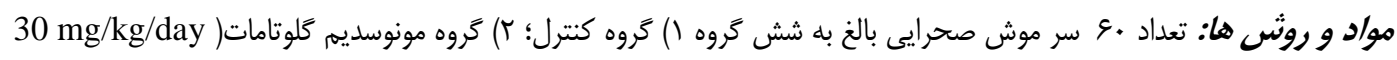

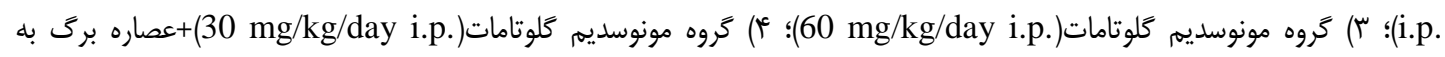

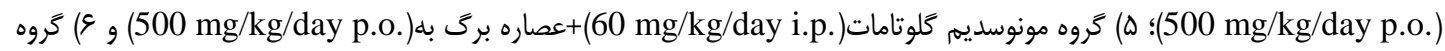

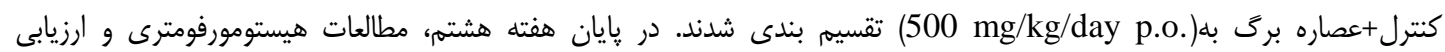

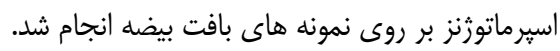

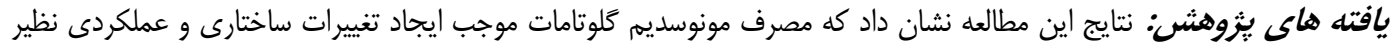

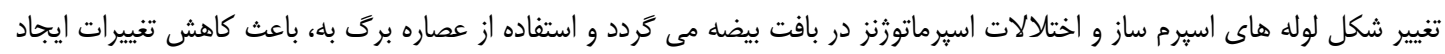
شده مى شود.

بحث و نتيجه تحيرى: با توجه به نتايج اين مطالعه استنباط مى شود كه استفاده از تركيبات آنتى اكسيدانى نظير بركى به، مى تواند

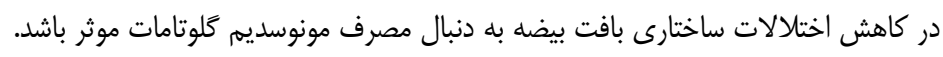

وازه هاى كليدى: هيستومورفومترى، مونوسديم گلوتامات، بركى به، موش صحرايى، بافت بيضه 
برگ بله، و نيز به دليل وجود اثرات سميت بافتى مقدمه مونوسديم كلوتامات بر بافت بيضه كه مى تواند از بران

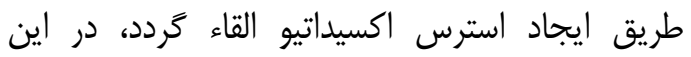

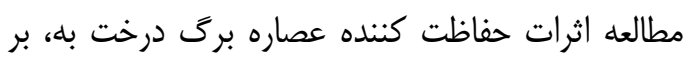
تغييرات سلولى و بافت شناسى بيضه متعاقب مصرف حناف

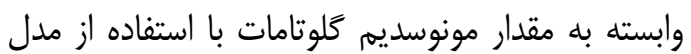
حيوانى بررسى گر ديد.

مواد و روش هانى برسى كرديل

حيوانات: براى انجام اين تحقيق از موش هاى هاى

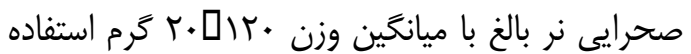
كرديد. حيوانات در محل يرورش و نتخهدارى حيوانات

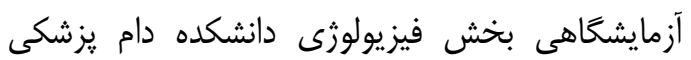

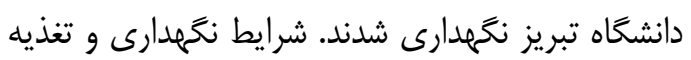
تمام حيوانات يكسان بود. اين حيوانات توسط يلت نئن تغذيه شدند و آب مصرفى آن ها از آب معمولى شهرى تامين گرديد. موش هاى صحرايى در درجه حرارت ابل

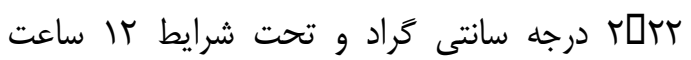

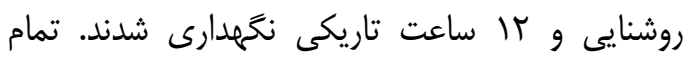

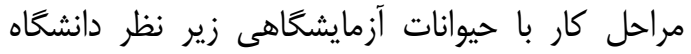

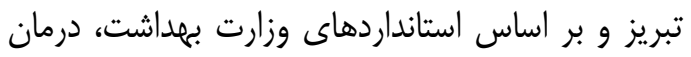

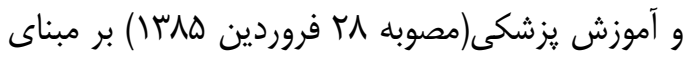
يروتوكل هلسينكى(Helsinki, Finland, 1975)

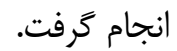

كروه بندى: تعداد •ع سر موش هاى صحرايى به

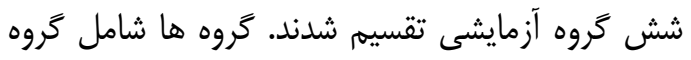

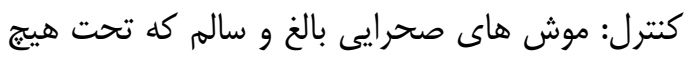

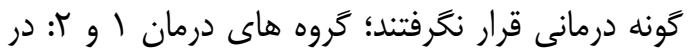

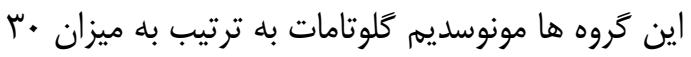

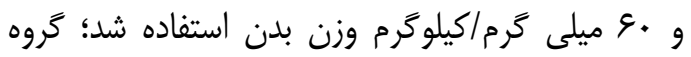

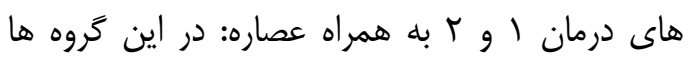

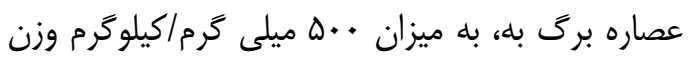
بدن در موش هاى دريافت كننده مونوسديم كلوتامات

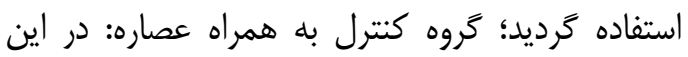

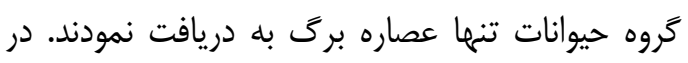
تمام گروه ها در انتهاى هفته هشتم نمونه گيرى از بافت بيضه به عمل آمد. جهت يكسان بودن شرايط

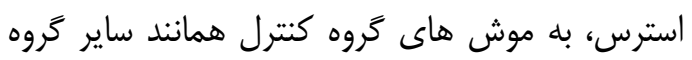
ها، هم حجم با محلول مونوسديم گلوتامات، آب مقطر ساير مكره

مونوسديم كلوتامات، تركيب نمك سديم وL-اسيد Fلوتاميك است و به عنوان تشديدكننده طعم به مواد غذايى اضافه مى گردد(1). اسيد كلوتاميك از اسيدهاى

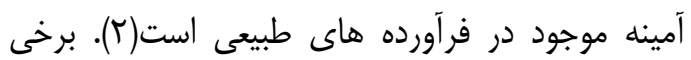
مطالعات به اثرات سميت بافتى اين تركيب بر بافت

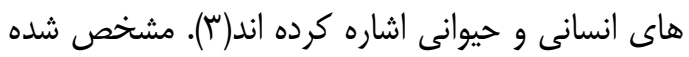

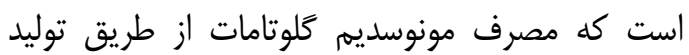

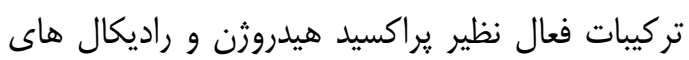
اكسيثن، باعث ايجاد فر آيند استرس اكسيداتيو مى شود.

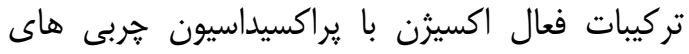

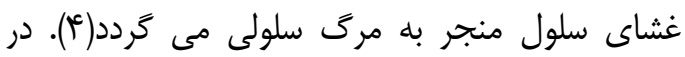

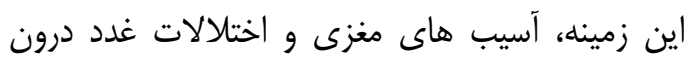

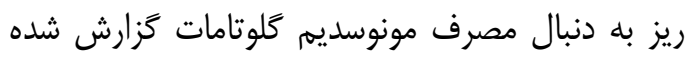
است(S.S). كاهش بارورى، كاهش ميزان رشد، كاهش

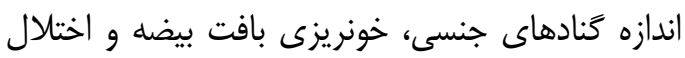

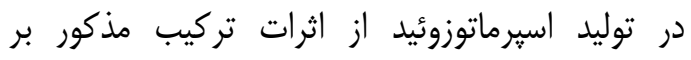

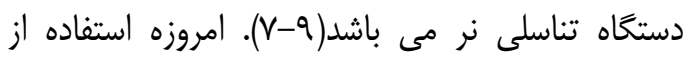
گياهان دارويى در درمان بيمارى هاى مختلف به دليل

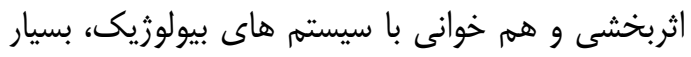

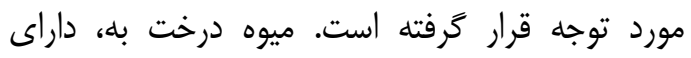
خواص آنتى اكسيدانى و ضد ميكروبى مى باشدار (1). برى درخت به، داراى خواص مختلف تسكين دهنده،

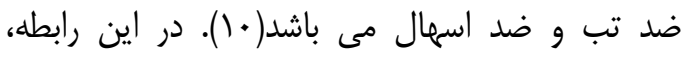

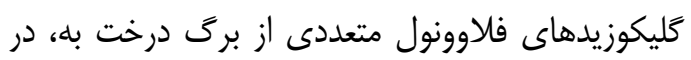

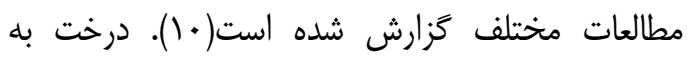
داراى خواص متعددى نظير ضد اسمال، ترميه كننده زخمه، ضد التهاب، ضد استفراغ مى باشد. ميوه به، در

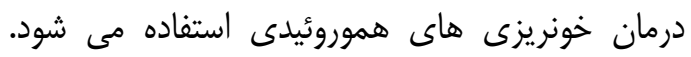

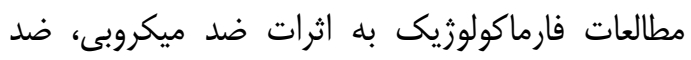
زخم، ضد حساسيت، ضد ديابتى و اثراتى نظير خاصيت

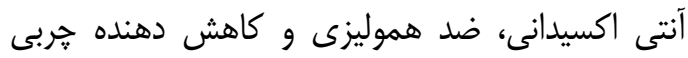

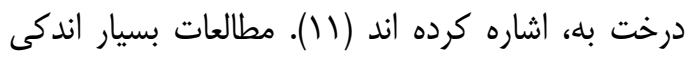

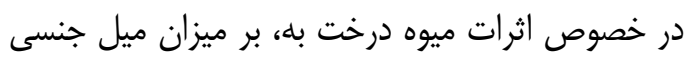

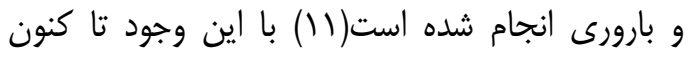
مطالعه اى در مورد اثرات برگى درخت به، بر ساختمان

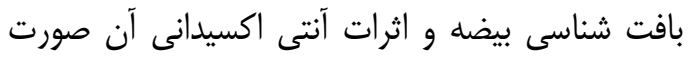
نخرفته است. با توجه به وجود خواص آنتى اكسيدانى أنى أنى أنى 
شد تا از لوله هايى با مقطع عرضى گرد و سايز تقريباً يكسان استفاده شود. به منظور ارزيابى اسبرماتوزنز در لوله هاى منى لمانى

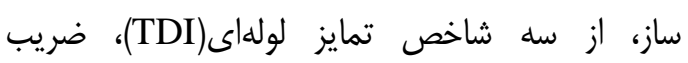
اسيرميوزنز(SPI) و شاخص تجديد جمعيت(RI) استفاده شد. براى محاسبه شاخص تمايز لوله ای، درصد لوله

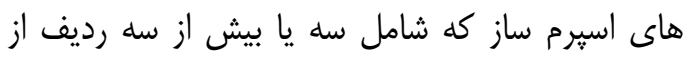

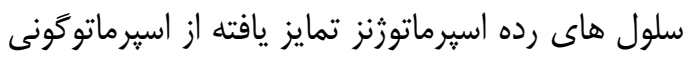

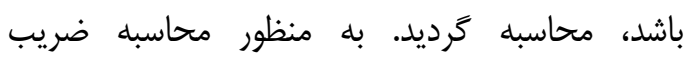
اسيرميوزنز، نسبت لوله هاى منى ساز حاوى اسيرم به لوله هاى فاقد اسيرم محاسبه شد. جهت محاسئ لناسيه

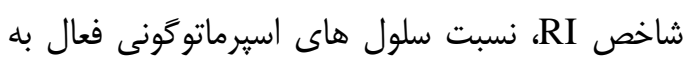

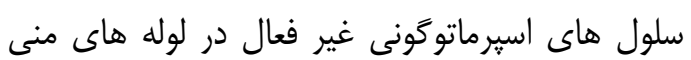

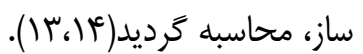
آناليز آمارى: در اين مطالعه، نتايج با استفاده از بسته نرم افزارى GraphPad PRISM نسخه 5.04

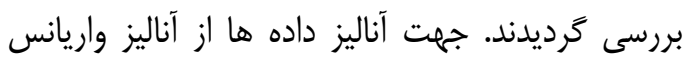
يك طرفه و تست تكميلى توكى براى مقايسه ميانگين

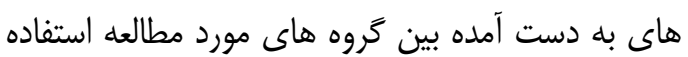

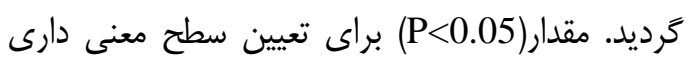
بين گروه ها در نظر گرفته شد.

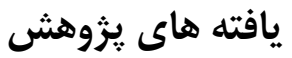

/رزيابى هيستومورفومترى بافت بيضه: نتايج حاصل

از اندازه كيرى ضخامت كِيسول همبندى بيضه نشان

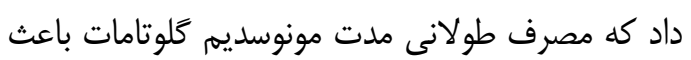

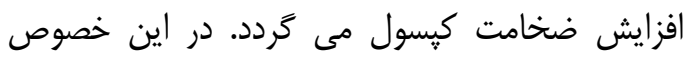
استفاده از عصاره برى بله، موجب كاهش ضخامت كيسول همبندى بيضه در مقايسه با گروه هاى دريافت كننده مونوسديم كلوتامات شد با اين وجود، تغييرات

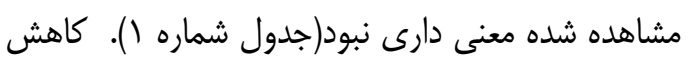
معنى دار قطر خارجى لوله هاى اسيرم ساز در دمارد تمام كروه ها در مقايسه با گروه كنترل مشاهده كرديد.

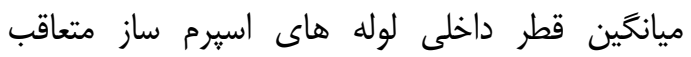

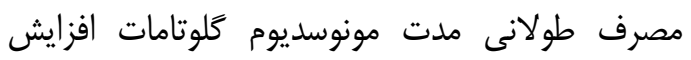
يافت، هر هند كه اين اختلاف بين گروه هاى مختلف

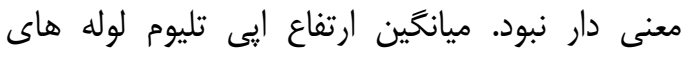

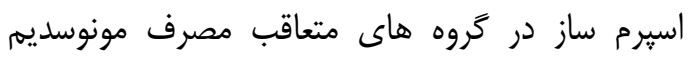

به صورت داخل صفاقى و هم حجم با عصاره برگ به، آب مقطر به روش كاواز دهانى در طول مدت آز حمايش

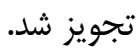

تهيه مونوسلديم كلوتامات و عصاره بركى به:

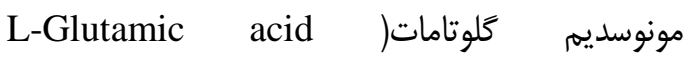
monosodium salt hydrate, sigma-aldrich, St Louis, MO 63178 USA

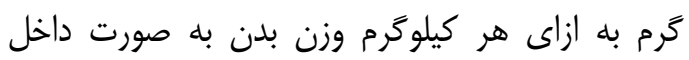

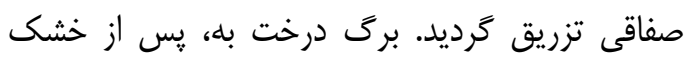

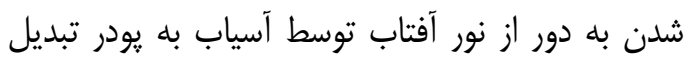

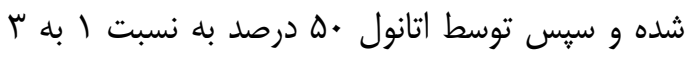

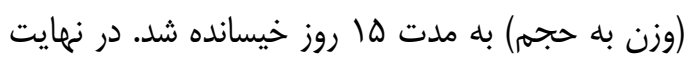

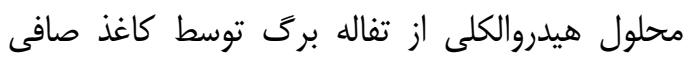
واتمن جداسازى شد. سيس با تقطير الكل، ماده

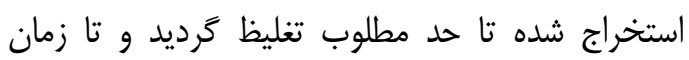

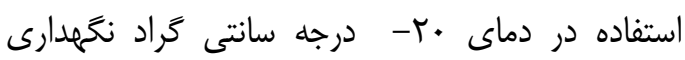
شد(r). (1). نمونه بردارى و مطالعات هيستومورفومترى:

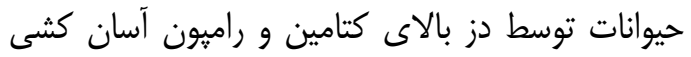
شدند سبس بيضه ها از بدن حيوانات جدا شدند و ونهات انجام مطالعات بافت شناسى در محلول فرمالين سرم جرات

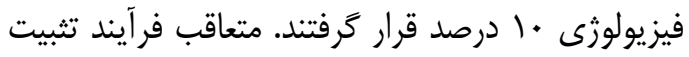
بافتى، مراحل پاساز بافت، قالب گيرى، برش قالب هاى

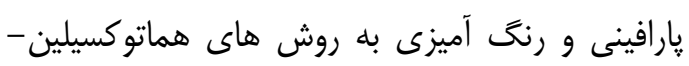
ائوزين و يريوديك اسيد شيف بر روى نمونه ها صورت

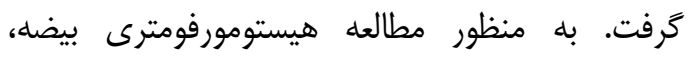
اسلايدهاى تهيه شده با درشت نمايى هاى مختلف با كمى عدسى مدرج موردبررسى قرار كرفتند. در مطالعه ماله مورفومتريك بافت بيضه، فاكتورهايى نظير ضخامت فئ فردئ كيسول همبندى، قطر خارجى لوله هاى منى ساز، باز

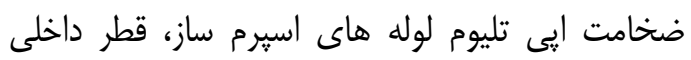

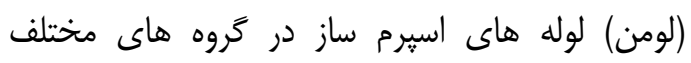

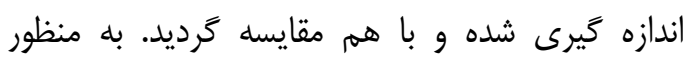
شمارش تعداد سلول هاى ديواره لوله هاى اسيرم ساز،

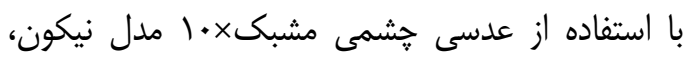

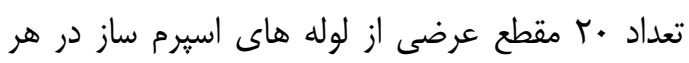

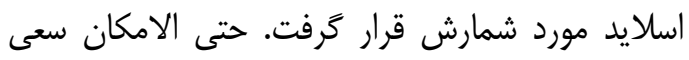


در مقايسه با گروه كنترل برخوردار بودند. هم جنين اين كاهش معنى دار(P<0.05) در تعداد سلول هاى مذكور

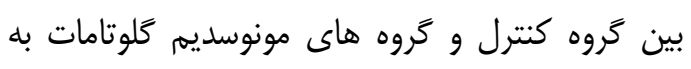
ميزان mg/kg • ع همراه عصاره و كنترل همراه عصاره نيز مشاهده كرديد. نتايج حاصل /ز بررسى ضرايب /سبرماتوزنز: نتايج به دست آمده از بررسى ضريب تمايز لوله هاى اسيرم

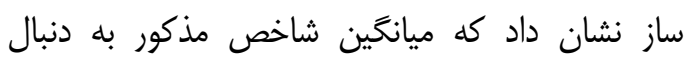

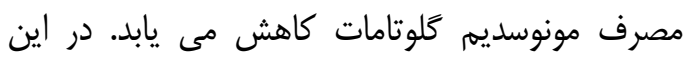
رابطه، مصرف عصاره برى بله، باعث افزايش ميانگين مئ ماين

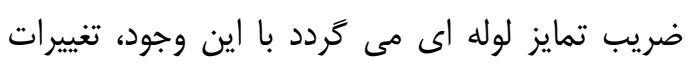
مشاهده شده به سطح معنى دار آمارى نرسيد(P) (P)

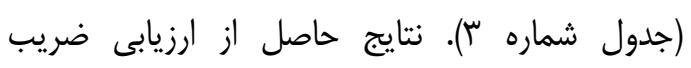

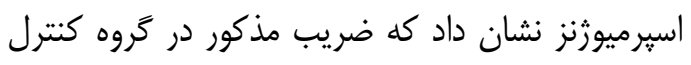

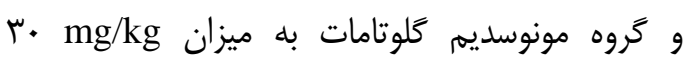

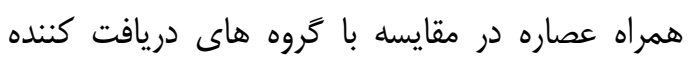

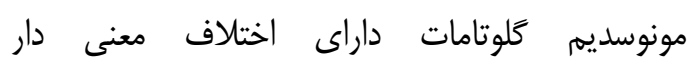

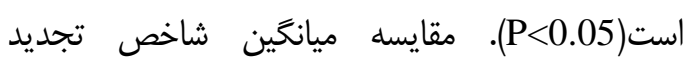
جمعيت بين گروههاى مختلف نشان داد كه شاخص

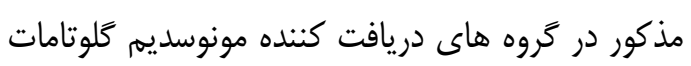

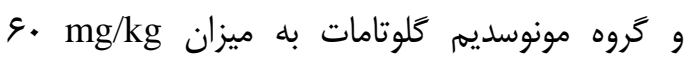

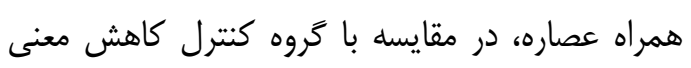
دارى يافت(P<0.05). مطالعات بافت شناسى بيضه: تصاوير شماره الى الى rا مقاطع بافت بيضه و لوله هاى اسيرم ساز را در كروه هاى تحت مطالعه نشان مى دهد. عمده تغييرات

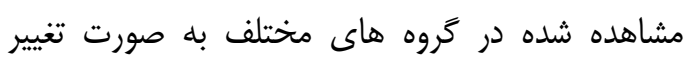
شكل لوله ها، كاهش جمعيت سلول هاى ديواره لوره لوله

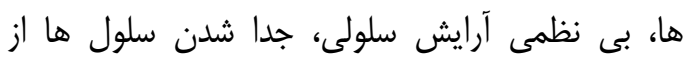
يكديخر و ادم بافت همبند بينابينى مشاهده كَرديد.
كلوتامات و عصاره برى به، در مقايسه با گروه كنترل كاهش معنى دارى يافت(جدول شماره ()). نتايج حاصل از شمارش سلول هاى دافي ديواره لوله هاى منى ساز: نتايج حاصل از شمارش سلول هار هاى ساى

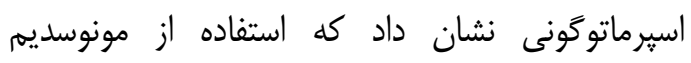

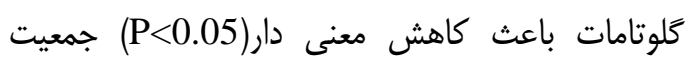

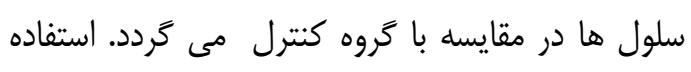

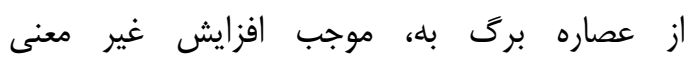

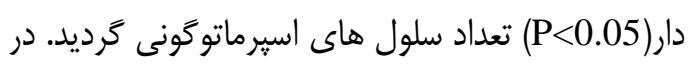
اين ميان، كاهش معنى دار(P<0.05) تعداد سلول هاى

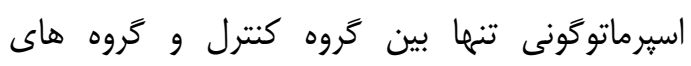

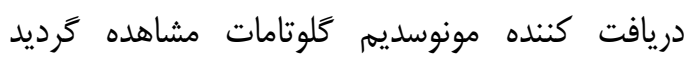

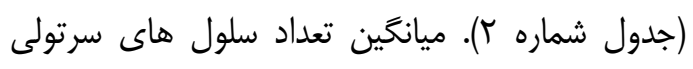
موجود در بخش قاعده اي لوله هاى اسيرم ساز در تمام

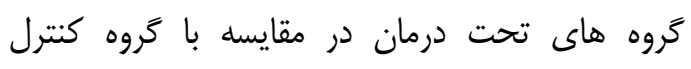

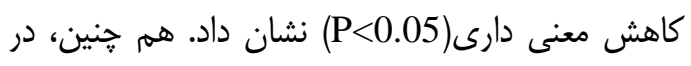

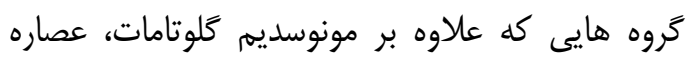

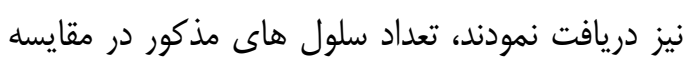

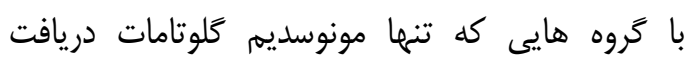

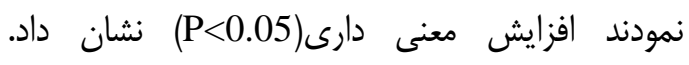
ميانكين تعداد سلول هاى اسبرماتوسيت اوليه در كروه هاى دريافت كننده مونوسديم كلوتامات در مقايسه با بان كروه كنترل كاهش معنى دارى(P<0.05) نشان داد.

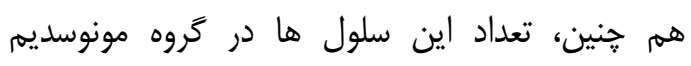

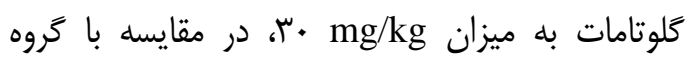

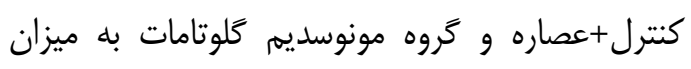

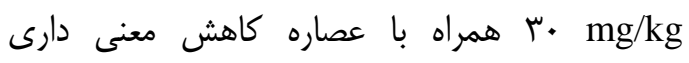
يافت(P<0.05). نتايج حاصل از شمارش تعداد سلول

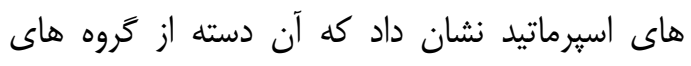

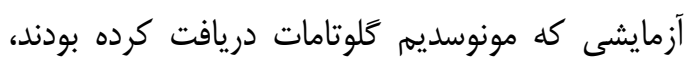

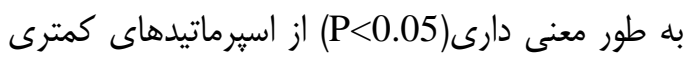


جدول شماره (. نتايج حاصل از مطالعات هيستومورفومترى بافت بيضه(بر حسب ميكرومتر)

\begin{tabular}{|c|c|c|c|c|}
\hline \multicolumn{4}{|c|}{ ميانكين شمارش سلوليهاى ديواره لوله هاى اسيرم ساز } & \multirow[t]{2}{*}{ كروه هاى تحت مطالعه } \\
\hline اسير ماتيد(تعداد در •ا لوله) & اسيرماتوسيت اوليه(تعداد در • الوله) & اسير ماتوكونى(تعداد در •ا لوله) & 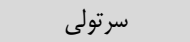 & \\
\hline$|\& \Lambda Y \pm I| V / \Lambda$ & $r q q / v \pm q / \wedge r \wedge$ & $r \Delta \Delta / V \pm 1 / v g r$ & $\Delta \varepsilon / \mu r \pm r / \Lambda \Lambda$. & 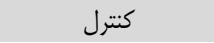 \\
\hline$\| \Delta \Lambda \pm V / T r f_{*}$ & 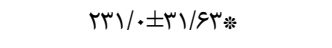 & $r \mu \pm I \Lambda / \Delta \Lambda *$ & $|V / r r \pm \cdot| M \mid * £$ & درمان \\
\hline$\| r \Lambda \pm Y Y / r \mid *$ & $r \Delta V / V \pm r V / q) *$ & $r T V / V \pm r V / \& 9 *$ & 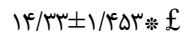 & 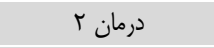 \\
\hline$|\uparrow \Psi \varepsilon \pm \Delta V / \Delta|$ & $\varphi \cdot \Gamma / \cdot \pm \Delta V / \& g €$ & $r r r / r \pm 1.9 / 1$ & 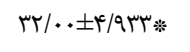 & درمان 1+عصاره \\
\hline$\eta r \cdot V \pm V r / \cdot r *$ & $r \varepsilon \Delta / \cdot \pm \mid r / q$. & 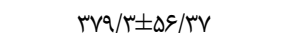 & TN/GV $\pm \cdot / r r \% * ¥$ & درمان r+عصاره \\
\hline $\mid r \cdot r \pm r \Psi / \cdot \varphi_{*}$ & $r \vee / v \pm \Delta / \xi \cdot \lambda €$ & | & 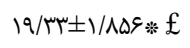 & كنترل + عصاره \\
\hline.$/ \cdots r$ &.$/ \cdot 1 r$ & . Hr. &.$/ \cdots 1$ & $\mathrm{P}$ \\
\hline
\end{tabular}

جدول شماره r. نتايج حاصل از مطالعات شمارش سلول هاى ديواره لوله هاى اسبرم ساز بافت بيضه

\begin{tabular}{|c|c|c|c|}
\hline \multicolumn{3}{|c|}{ شاخص هاى اسبرماتورنز } & \multirow[t]{2}{*}{ كروه هاى تحت مطالعه } \\
\hline RI (\%) & SPI (\%) & TDI (\%) & \\
\hline$\vee Q / ৭ \& \pm r / 11 \Delta$ & $1 \cdot \cdot 1 \cdot \pm \cdot 1 \cdot$ & $1 \cdot \cdot \pm \cdot, \cdot$ & كنترل \\
\hline$\varepsilon V / r \wedge \pm r / \cdot \wedge r £$ & $9.1 . . \pm . / . * €$ & N & درمان 1 \\
\hline$s \varphi / \Delta f \pm r / .1 . £$ & 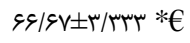 & سזس/ & درمان r \\
\hline$V r / ৭ ৭ \pm r / r .$. & سبr/\% & $\Lambda / 9 V \pm 9 / 99 \mathrm{~V}$ & درمان |+عصاره \\
\hline SQ/DTIT/YGK $£$ & $V \varepsilon / 9 V \pm \varepsilon / 99 V$ & $q \Psi / \mu \pm \Phi / 99 V$ & درمان r+عصاره \\
\hline$V \cdot / / r \pm I / N E \Lambda$ & $V / r / r \pm I r / r$ & $9.1 \cdot \pm \cdot 1$. & كنترل + عصاره \\
\hline.$\cdots r$ & אr... & . /reA. & $\mathrm{P}$ \\
\hline
\end{tabular}

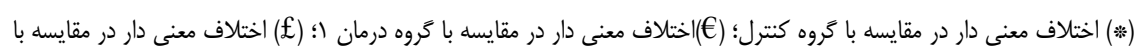

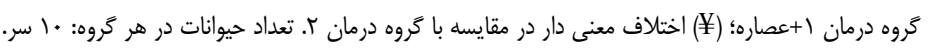

جدول شماره س. ميانكَين شاخص هاى اسبرماتوزنز در تَروه هاى مختلف

\begin{tabular}{|c|c|c|c|c|}
\hline \multicolumn{4}{|c|}{ هيستومورفومترى بافت بيضه } & \multirow[t]{2}{*}{ كروه هاى تحت مطالعه } \\
\hline ارتفاع إيتليوم & قطر داخلى لوله & قطر خارجى لوله & ضخامت كِّول & \\
\hline$r M N / r \pm \Delta / r Y T$ & $\mid V q / r \pm r / \cdot \wedge V$ & $r g V / r \pm D / A V G$ & $9 \Delta / \Delta T \pm I / ৭ 9 \vee$ & كنترل \\
\hline$r r q / \kappa \pm \varepsilon / V I r^{*}$ & $\mid V q / V \pm r / q V V$ & $\varphi \cdot q / \cdot \pm q / \uparrow q \cdot *$ & $g g / \wedge r \pm r / F V \Delta$ & درمان 1 \\
\hline$r \Gamma N / \Lambda \pm \Delta / q \ldots *$ & $\mid N E / \cdot \pm r / M F V$ & $\lceil\mid r / q \pm r / 9 r \Delta * *$ & $G 9 / Q \vee \pm r / r r$. & درمان T \\
\hline$r \Gamma \Delta / r \pm \Delta / \digamma \Phi Q) *$ & $\mid \Lambda \Gamma / q \pm r / \cdot \uparrow \wedge$ & $\tau \cdot q / r \pm \Gamma / V \Delta V *$ & $9 r / 1 \cdot \pm r / \Lambda) I$ & درمان (+عصاره \\
\hline$r \mid \varepsilon / \varepsilon \pm \Delta / A r \varepsilon *$ & $M \cdot / r \pm r / N r q$ & $\Gamma q 9 / q \pm V / q \Delta \rho *$ & $q F / F \cdot \pm r / I m 4$ & درمان r+عصاره \\
\hline$r \Gamma q / \Delta \pm r / r / \Delta *$ & 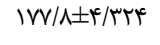 & $\Gamma \cdot V / V \pm V / \Delta \uparrow \wedge *$ & $99 / \Upsilon \wedge \pm \Gamma / \backslash \wedge q$ & كنترل + عصاره \\
\hline.$/ \ldots 1$ &.$/ 4 V I I$ &.$/ \ldots 1$ & ./^५१q & $\mathrm{P}$ \\
\hline
\end{tabular}

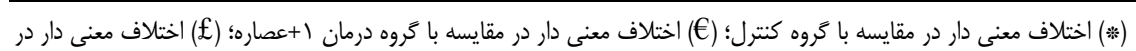

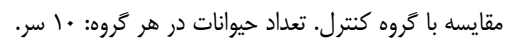




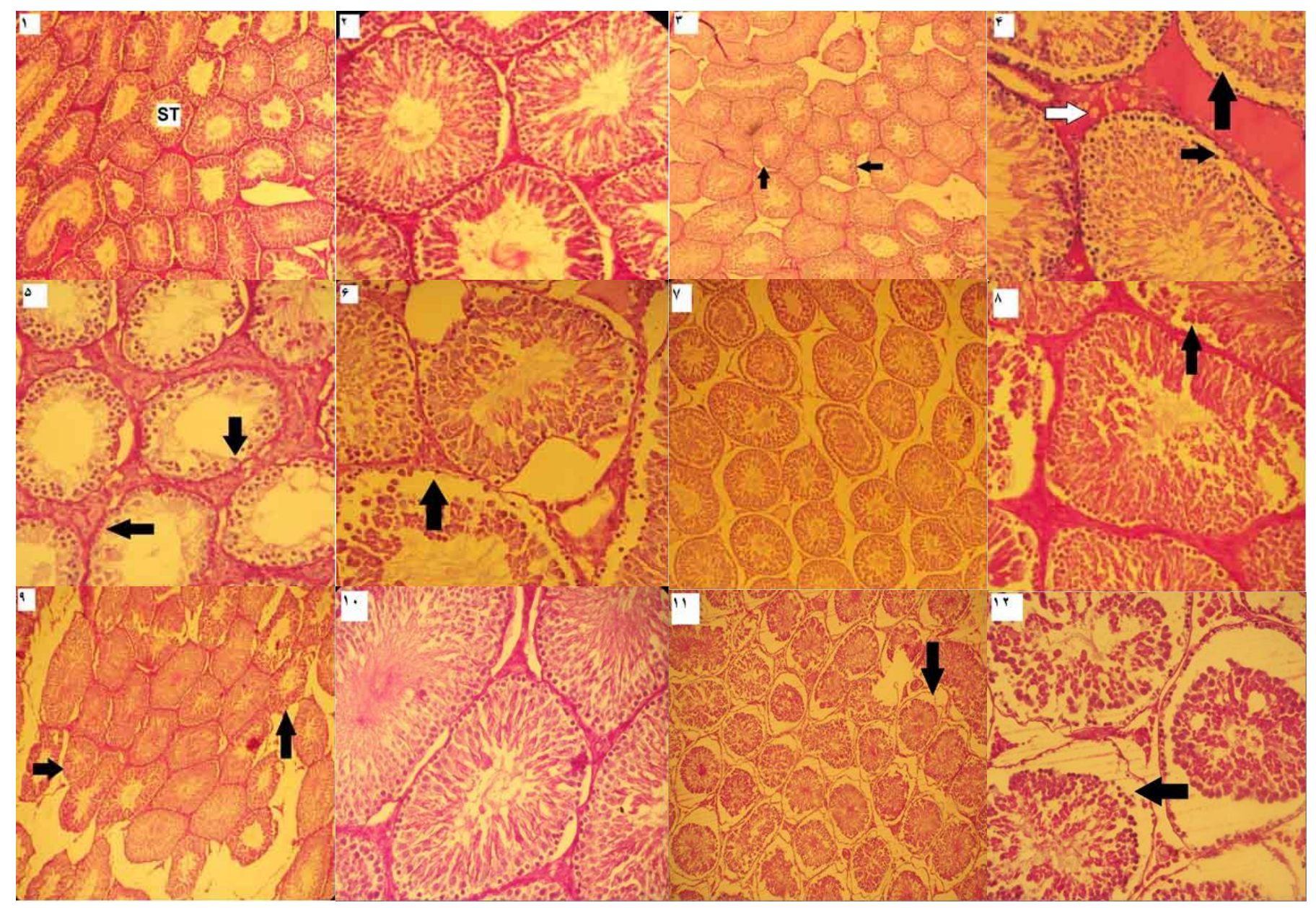

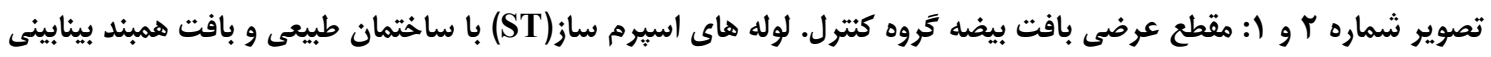

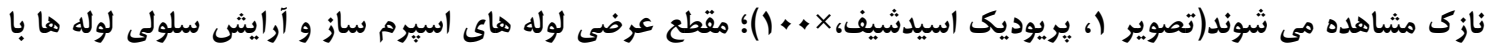

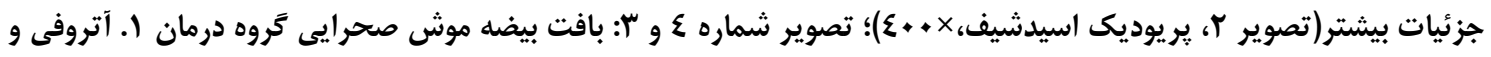

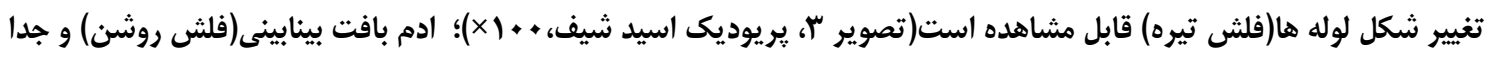

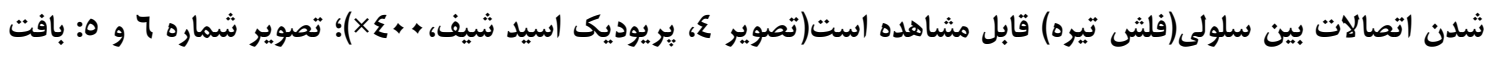

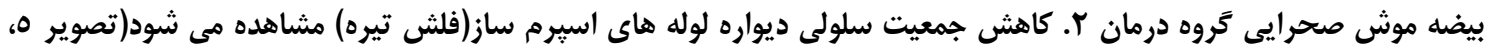

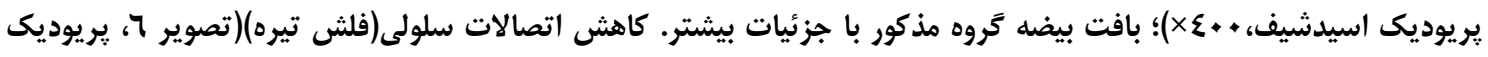

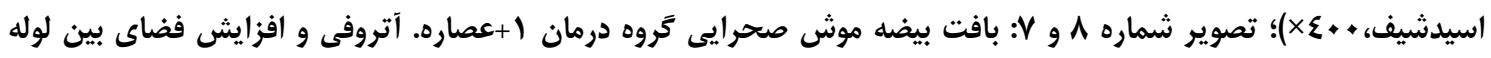

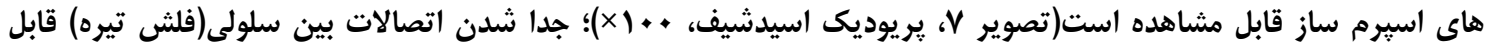

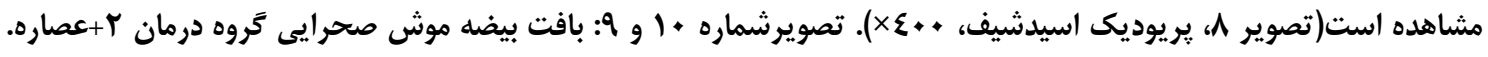

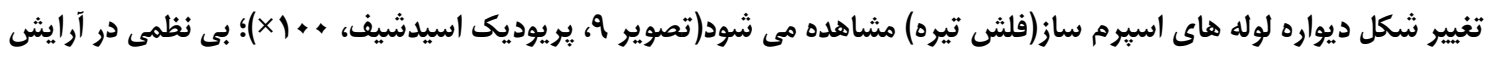

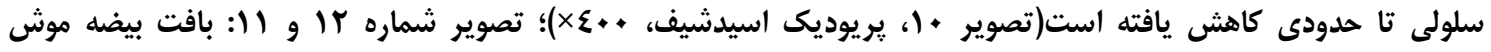

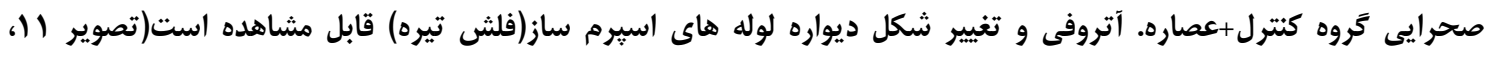

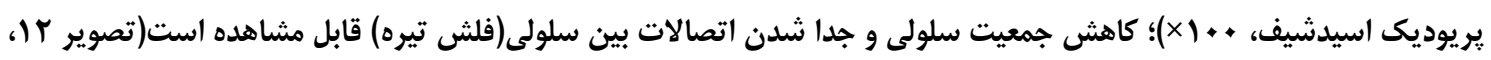


جنين، تغييراتى نظير متراكم شدن كروماتين هسته سلول هاى رده اسيرماتوزنز و يرخونى عروق خونى نيز اشاره شده است(آ). در تحقيق ديخرى به به آسيب إيتليوم زايخر و سلول هاى ليديخ در موش هاى تازه متولد شده متعاقب مصرف مونوسديم كلوتامات اشاره

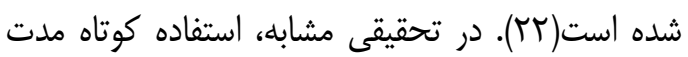

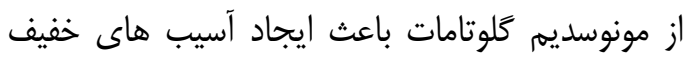
تا متوسط در لوله هاى اسيرم ساز نظير تشكيل واكوئل

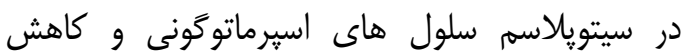
جمعيت سلول هاى اسيرماتيد و افزايش فضاى بين سلواني لولههاى اسيرم ساز شده است(سٓ). در همين ارتباط، استفاده طولانى مدت از تركيب مذكور باعث ايجاد آسيب هاى شديد در سلول هاى زايخر و ايجاد توده إنها هاى سلولى نكروتيك در بسيارى از لوله ها شده است. در اين خصوص، برخى محققين اشاره مى كنند كه بروز تغييرات بافت شناسى در لوله هاى اسيرم ساز متعاقب دئ دان

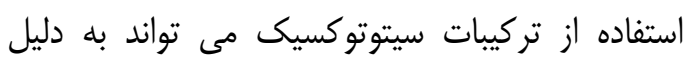

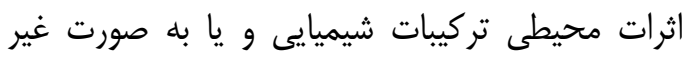

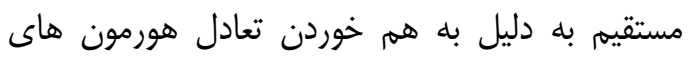

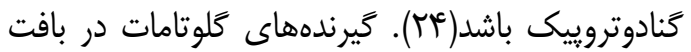
هاى مختلفى نظير هييوتالاموس، طحال، تيموس، كبد،

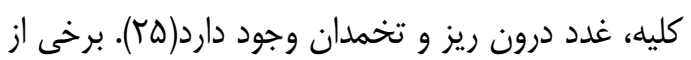

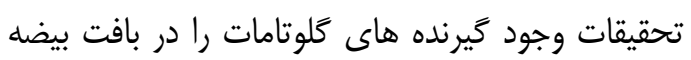

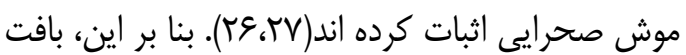
بيضه مى تواند به عنوان اندام هدف، تحت تاثير اثرات

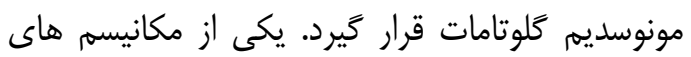
احتمالى مشاهده اختلالات ساختارى و عملكردى بات بافت

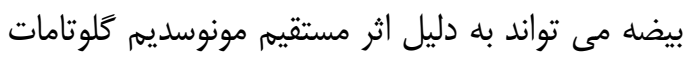

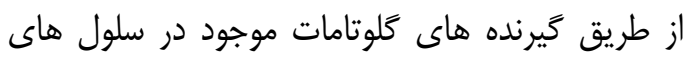

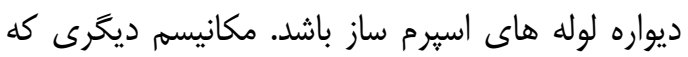
در برخى از تحقيقات در خصوص اختالالات اسيرماتوزنز به آن اشاره شده است، اثرات سميت عصبى مونوسديم

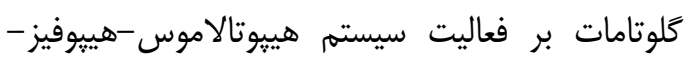

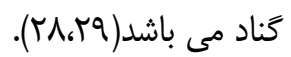
امروزه مشخص شده است كه تركيبات فلاوونوئيد درخت بله، داراى اثرات آنتى اكسيدانى قوى و اثرات

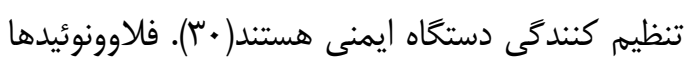

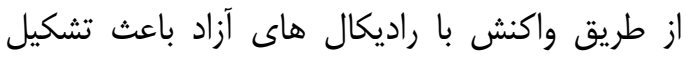

\section{بحث و نتيجه كيرى}

در اين مطالعه اثرات عصاره برى بلهي، متعاقب

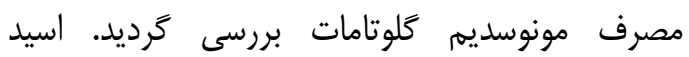

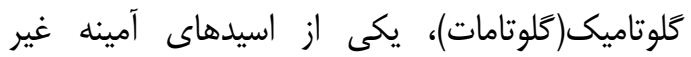
ضرورى موجود در يروتئين ها است. كلوتامات داراى آنائ نقش هاى متعددى در فعاليت سلول هاى بلدن است. از

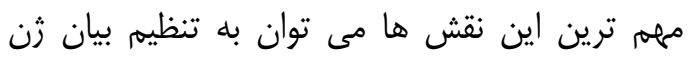

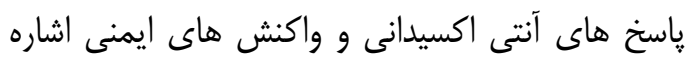

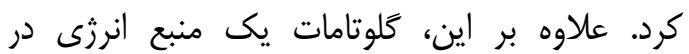

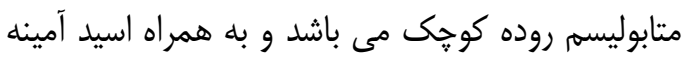

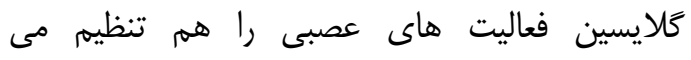
كند(ها). در ابتدا تصور بر اين بود كه استفاده ازئ

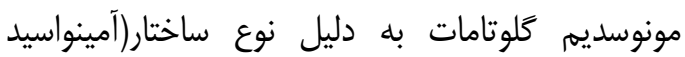

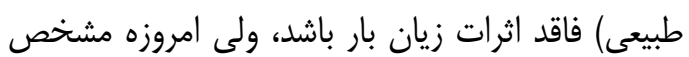

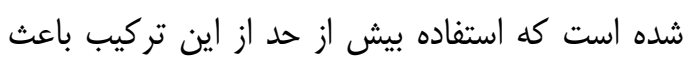

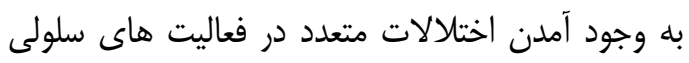

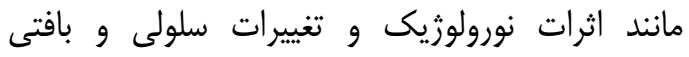

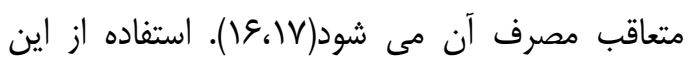

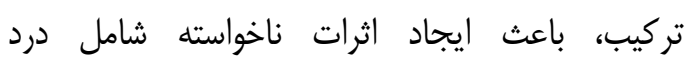
عضلانى، تعريق، سردرد، واكنش هاى آلرزيك و آسم آسمات ناته

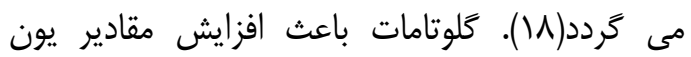
كلسيم داخل سلولى مى شود كه مى توداند باند باعث آسيب

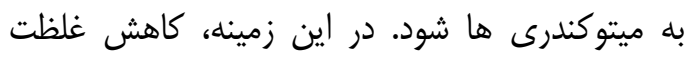

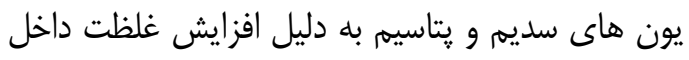

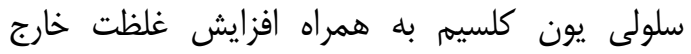
سلولى روى، مى تواند باعث ايجاد آسيب هاى ناى ناء

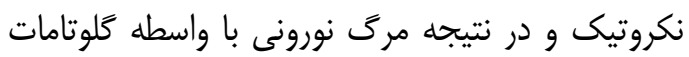

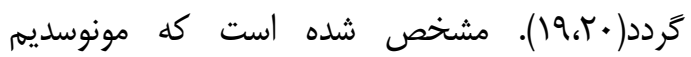
كلوتامات باعث ايجاد فرآيند استرس اكسيداتيو مى ثى إنى شود. در اين شرايط تركيبات فعالى نظير يراكسيد

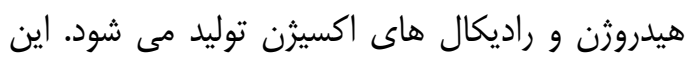
تركيبات فعال باعث آسيب DNA و هير هيراكسيداسيون جربى هاى غشاى سلول مى گرَدد كه در نهايت منجر

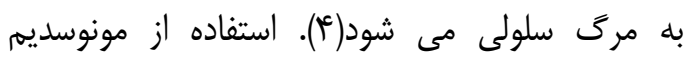

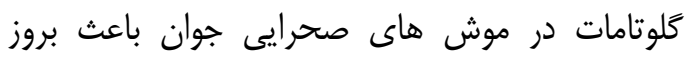
تغييراتى نظير آتروفى لوله هاى اسيرم ساز، تورم سلول

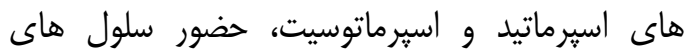
زايخر نابالغ در حفره داخلى لوله ها شده است. هم 
هم جنين برخى مطالعات كزارش كرده اند كه استفاده از مونوسديم كلوتامات در موش هاى صحر ايیى بالغ باعث ايجاد تغييرات آتروفى در بافت بيضه و كاهش دون هات تعداد سلول هاى سرتولى و سلول هاى ليديخ شئ شده

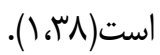

استفاده كوتاه مدت از مونوسديم كلوتامات تشكيل

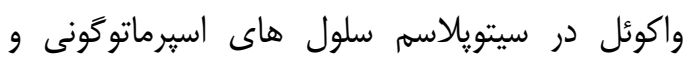

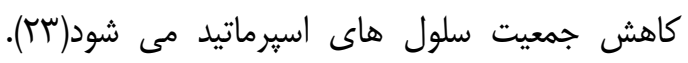

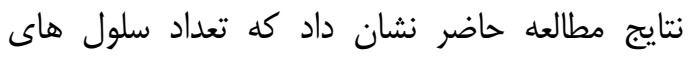

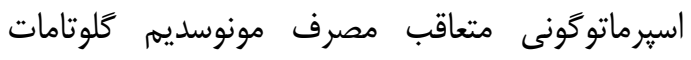
كاهش مى يابد، شدت اين كاهش در مواقع استفاده از

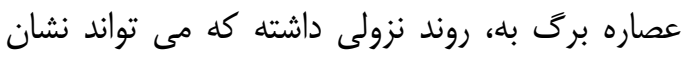

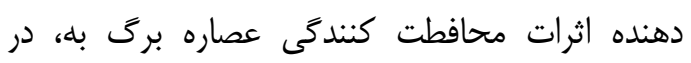
مقابل تغييرات جمعيتى در اين سلول ها باشد. هر هند إند

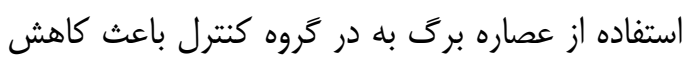

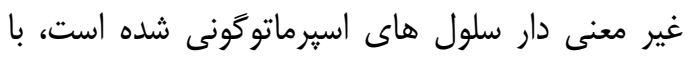
اين وجود به نظر مى رسد افزايش تعداد سلول هاى سلى هاى مذكور در كروه هاى دريافت كننده مونوسديم كلوتامات

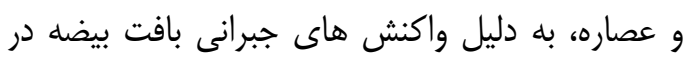
حضور ويزگى هاى آنتى اكسيدانى عصاره برى بـ به باشد. نتايج اين مطالعه نشان داد كه مصرف مونوسديم

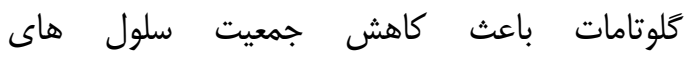
اسبرماتوسيت مى كردد. با توجه به اين كه استفاده از

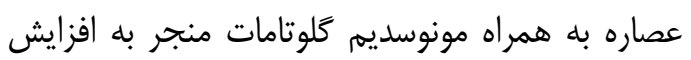
تعداد سلول هاى اسيرماتوسيت شدهاست، بنا بر اين

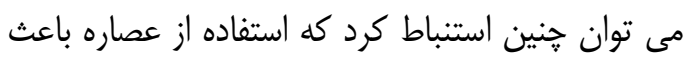

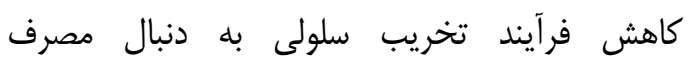

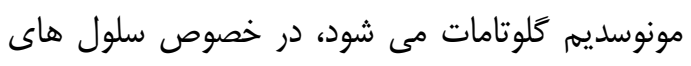

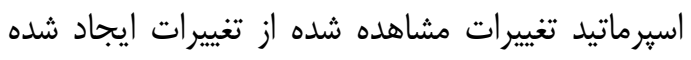
در سلول هاى اسيرماتوسيت تبعيت مى كند. برخى

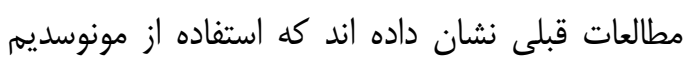
كلوتامات در موش هاى صحرايى باعث توان تورم سلول

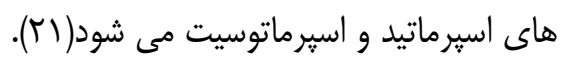

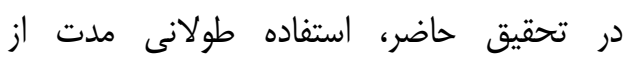

مونوسديم كلوتامات باعث كاهش قطر خارجى لوله

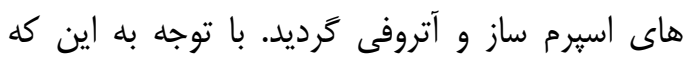

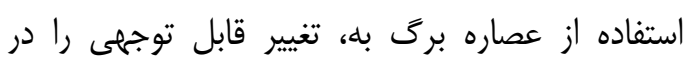

راديكال هاى يايدار با سميت پايين مى شوند هم

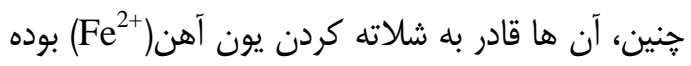

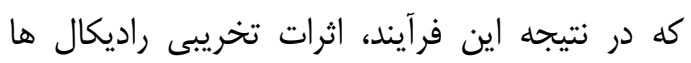

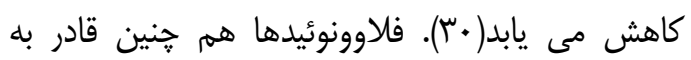
مهار ترشح واسطه هاى التهابى نظير اكسيد نيتريك،

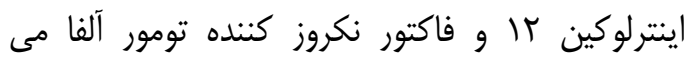
باشند(ץس، آ). درخت به داراى مقادير فراوانى اسيدهاى

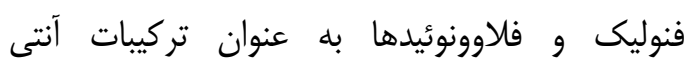

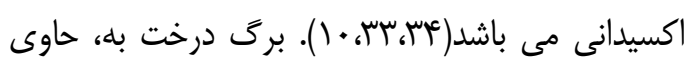

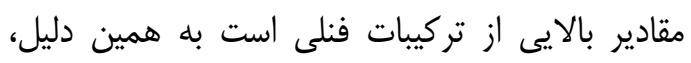

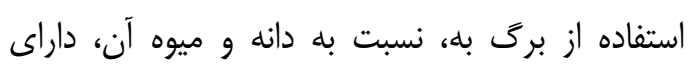

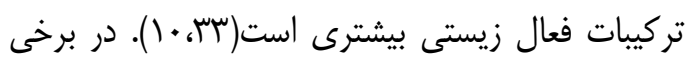
از تحقيقات به كاهش واكنش هاى اكسيداتيو متعاقب لتبن مصرف تركيبات فلاوونوئيدى اشاره شده است(هَّ، آس). در مطالعه اى كه جهت شناسايى تركيبات اركانيك

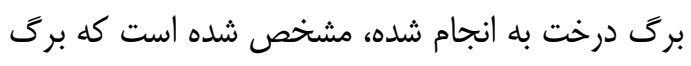

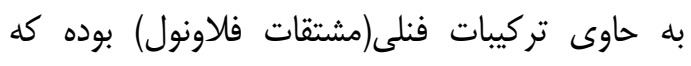

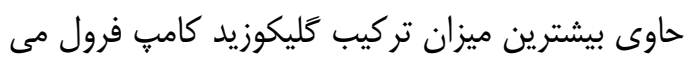

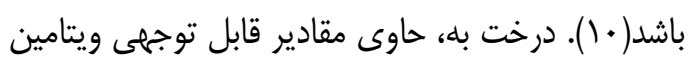
E

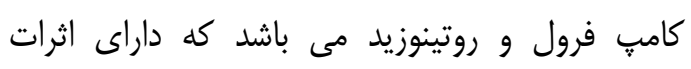

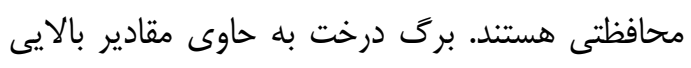

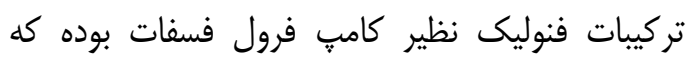

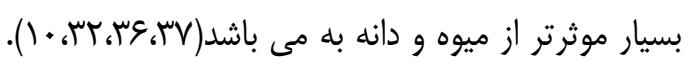
در اين مطالعه، با افزايش ميزان مونوسديم مكلوتامات،

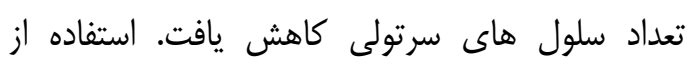

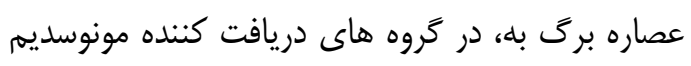
كلوتامات، باعث افزايش معنى دار تعداد سلول هاى هاى درئ كائن

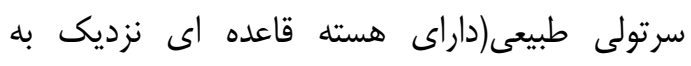

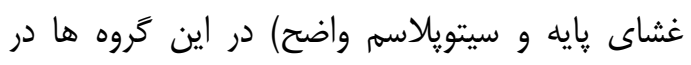
مقايسه با گروه هايى كه تنها مونوسديم كلوتامات

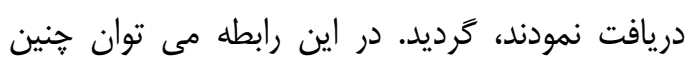

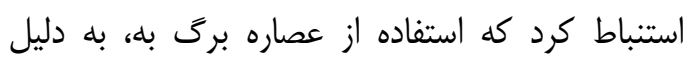

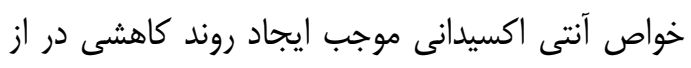
بين رفتن جمعيت سلول هاى سرتولى طبيعى مى شود.

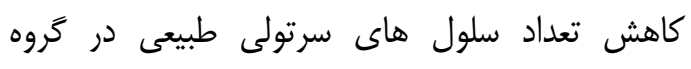
كنترل دريافت كننده عصاره مى تواند به دليل برل بروز برخى تغييرات ساختارى در لوله هاى اسيرم ساز باشد. 
دار درصد لوله هاى فاقد اسيرم منجر گردد. در اين ميان، بهبود ضريب تمايز لوله ایى در گروه هاى دريافت

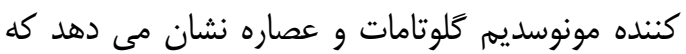
استفاده از عصاره برى به، موجب كاهش ميزان تعداد سلول هاى از بين رفته و بهبود فرآيند تكثير و تمايز سلولى مى شود. با توجه به كاهش تعداد سلول هاى

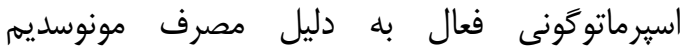

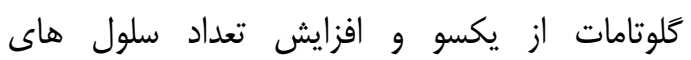
اسيرماتوگونى فعال متعاقب استفاده از عصاره برى به، از سوى ديخر مى توان نتيجه گرفت كه كاهش تعداد سلول هاى اسبرماتوكونى فعال خود از دلايل كاهش ناه

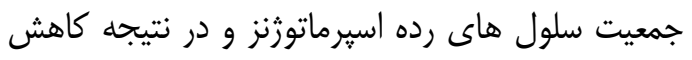

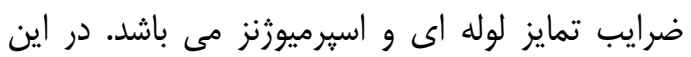
رابطه برخى محققين كزارش كرده اند كه استفاده از مونوسديم كلوتامات باعث كاهش جمعيت سلول هاى

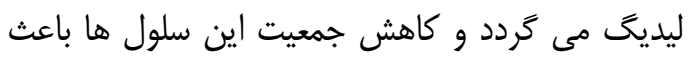
كاهش توليد هورمون هاى استروئيدى و در نتيجه اختالال در فرآيند اسيرماتوزنز مى شود(أ). به طور كلى از مطالعه حاضر هنين نتيجه كيرى مى شود كه

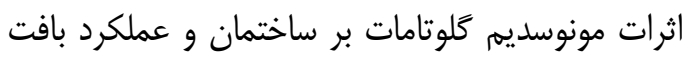
بيضه وابسته به ميزان اين تركيب مى باشد و استفاده از عصاره برى به، با توجه به وجود خواص آنتى اكسيدانى

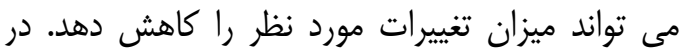
اين ميان، تاثير استفاده دراز مدت عصاره برى بله، بر بافت بيضه نياز به مطالعات بيشتر دارد. سباسكز ارى نويسندكان، بدين وسيله از حمايت هاى معاونت محترم يثوهشى دانشكاه تبريز در انجام اين يروزه

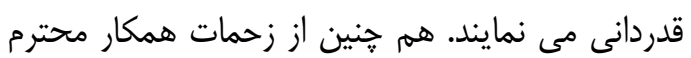

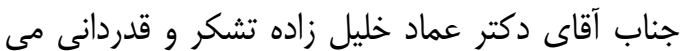

\section{Referenses}

1.Moore KL. Congenital malformations due to environment. In: Developing Humans. $2^{\text {nd }}$ ed. Philadelphia WB Saunders Publication.2003;P.173-83.

2.Adrienne S. The toxicity safety of MSG. Acct Res 1999; 6:259-310.
ميزان قطر خارجى لوله ها ايجاد نكرد، مى توان جنين

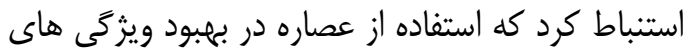
ساختارى لوله هاى اسيرم ساز تاثيرى ندارد. عدم مشاهده اختلاف معنى دار در قطر داخلى لوله هاى اسبرم ساز در گروه هاى دريافت كننده مونوسديم كلوتامات از يك سو و تغييرات ارتفاع إيتليوم زايخر در كروه هاى مختلف از سوى ديخر نشان دهنده كاهش

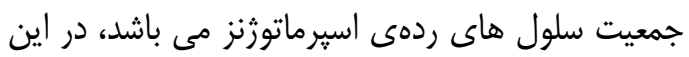
رابطه نتايج حاصل از مطالعات هيستومورفومترى به دست آمده با نتايج حاصل از شمارش سلول هم خوانى دارد. هم جنين برخى مطالعات كزارش كرده اند كه با مصرف مونوسديم كلوتامات قطر لوله هاى اسيرمساز و وارئ ارتفاع اييتليوم زايخر كاهش ييدا مى كند(وسج).

افزايش ضخامت كيسول همبندى بيضه به دنبال مصرف مونوسديم كلوتامات نشان دهنده آتروفى بافت بيضه مى باشد. در اين رابطه، استفاده از عصاره برى به، باعث كاهش ضخامت كِيسول بيضه در مقايسه با با گروه دريافت كننده مونوسديم كلوتامات شده است كه مى تواند نشان دهنده افت روند آتروفى شدن بيضه هات متعاقب مصرف عصاره برگ به به باشد. در اين زمينه،

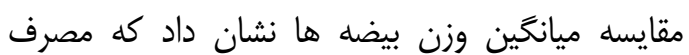
مونوسديم كلوتامات باعث كاهش وزن بيضه ها مى كردد. در برخى مطالعات گزارش شده است كه متعاقب مصرف مونوسديم كلوتامات فضاى بين لوله هاى دراى

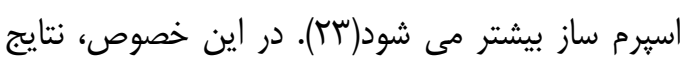
يك مطالعه نشان داد كه با مصرف مونوسديم كلوتامات

$$
\text { وزن بيضه كاهش مى يابد(• (ז). }
$$

نتايج حاصل از اين مطالعه نشان داد كادئ كه استفاده از

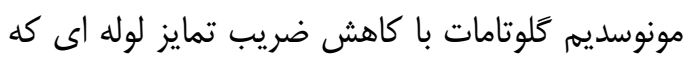
نشان دهنده كاهش جمعيت سلولى در نتيجه كاهش تقسيمات سلولى و كاهش اتصالات بين سلولى است،

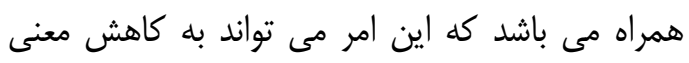

3.Andrew OE. Histological studies of the effects of monosodium glutamate on the kidney of adult wistar Rats. Int $\mathbf{J}$ Health 2007; 6:1.

4.Ahluwalia P, Tewari K, Choudhary P. Studies on the effects of monosodium glutamate on oxidative stress in 
erythrocytes of adult male mice. Toxicol Lett 1996; 84:161-5.

5.Miksowiak B, Partyka M. Effects of neonatal treatment with MSG (monosodium glutamate) on hypothalamo pituitarythyroid axis in adult male Rats. Histol Histopathol 1993;8:731-4.

6.Mozes S, Sefeikova Z. Obesity and changes of alkaline phosphatase activity in the small intestine of 40 and 80-day old rats subjected to early postnatal overfeeding of monosodium glutamate. Physiol Res 2004; 53(2):177-86.

7.Onakewhor JUE, Oforofuo IAO, Singh SP. Chronic administration of monosodium glutamate induces oligozoospermia and glucogen accumulation in wistar Rat testes. Africa J Rep Health 1998; 2:190-7.

8.Pizzi WJ, Barnhart JE, Unnerstall JR. Reproductive dysfunction in male rats following neonatal administration of monosodium L-glutamate. Neurobehav Toxicol 1979; 1:1-4.

9. Oforofuo IAO, Onakewhor JUE, Idaewor PE. The effect of chronic administration of MSG on the histology of the adult wistar Rat testis. Biosci Res Comm 1997; 9:1-2. 10. Oliveira AP, Pereira JA, Andrade PB, Valentao P, Seabra RM, Silva BM. Organic acids composition of Cydonia oblonga miller leaf. Food Chem 2008; 111: 393-9.

11.Aslam M, Sial AA. Effect of hydroalcoholic extract of Cydonia oblonga miller on sexual behaviour of wistar Rats. Adv Pharmacol Sci 2014; 2014: 282698.

12.Rodrigues AL, Silva GL, Mateussi AS, Fernandes ES, Miguel OG, Yunes RA, et al. Involvement of monoaminergic system in theantidepressant like effect of the hydroalcoholic extract of Siphocampylusverticillatus. Life Sci 2002; 70:1347-58.

13.Meistrich M, Wilson G, Porter K. Restoration of spermatogenesis in DBCPtreated rats by hormone suppression. Toxicol Sci 2003; 76:418-26.

14. Shetty G, Wilson G, Huhtaniemi I, Shuttlesworth GA, Reissmann T, Meistrich ML. Gonadotropin releasing hormone analogs and testosterone inhibits the recovery of spermatogenesis in irradiated Rats. Endocrinology 2000; 141:1735-45.

15.Wu G. Functional amino acids in growth reproduction and health. Adv Nut Int Rev J 2010; 1:31-7.
16.Beaszarate C, Perezvega MI, Gonzalezburgos I. Neonatal exposure to monosodium L-glutamate induces loss of neurons and cytoarchitectural alterations in hippocampal CA1 pyramidal neurons of adult Rats. Brain Res 2002; 952: 275-81.

17.Reis HJ, Guatimosim C, Paquet M, Santos M, Ribeiro FM, Kummer A, et al. Neuro-transmitters in the central nervous system and their implication in learning and memory processes. Curr Med Chem 2009; 16: 796-40.

18.Geha RS, Beiser A, Ren C, Patterson R, Greenberger PA, Grammer LC, et al. Multicenter double blind placebo controlled multiple challenge evaluation of reported reactions to monosodium glutamate. $\mathrm{J}$ Allergy Clin Immunol 2000; 106: 973-80.

19.Frandsen A, Schousboe A. Mobilization of dantrolene sensitive intracellular calcium pools is involved in the cytotoxicity induced by quisqualate and N-methyl-Daspartate but not by 2-amino-3-(3-hydroxy5-methylisoxazol-4-yl) propionate and kainate in cultured cerebral cortical neurons. Proc Natl Acad Sci 1992; 89: 2590-94.

20.Gillessen T, Budd SL, Lipton SA. Excitatory amino acid neurotoxicity in molecular and cellular biology of neuroprotection in the CNS. Springer Publishing. 2002;P.3-40.

21.Ismail NH. Assessment of DNA damage in testes from young wistar male Rat treated with monosodium glutamate. Life Sci J 2012; 9: 930-9.

22.Das RS, Ghosh SK. Long-term effects of monosodium glutamate on spermatogenesis following neonatal exposure in albino mice-A histological study. Nepal Med Coll J 2010; 12: 149-53.

23.Mohamed IK. The Effects of oral dosage of monosodium glutamate applied for shortand long-terms on the histology and ultrastructure of testes of the adult Rats. J Anim Vet Adv 2012; 11: 124-33.

24.Atallah OAA. Experimental nitrate nitrite and hydroxylamine toxicosis in the guinea Pig. Diss Abs1966; 27:31604.

25.Gill S, Pulido O. Glutamate receptors in peripheral tissue excitatory transmission outside the CNS. New York Kluwer Acad Plenum Publishing. 2005; P.3-26.

26.Gill SS, Mueller RW, Mcguire PF, Pulido OM. Potential target sites in 
peripheral tissues for excitatory neurotransmission and excitotoxicity. Toxicol Pathol2000;28:277-84. 27.Takarada TE, Hinoi VJ, Balcar $\mathrm{H}$, Taniura Y. Possible expression of functional glutarnate transporters in the Rat testis. J Endocrinol 2004; 181:233-44.

28. Giovambattista AES, Suescun MIAO, Nessralla CC, Franca LR, Spinedi E, Calandra RS. Modulatory effects of leptin on Leydig cell function of normal and hyperleptinemic Rats. Neuroendocrinology 2003; 78:270-9.

29.Gong SL, Xia FQ, Wei J, Li XY, Sun $\mathrm{TH}, \mathrm{Lu} \mathrm{Z}$, et al. Harmful effects of MSG on function of hypothalamus pituitary target gland system. Biomed Environ Sci 1995; 8: 310-17.

30.Nijveldt RJ, Vannood E, Vanhoorn DE, Boelens PG, Van Norren K, Vanleeuwen PA. Flavonoids a review of probable mechanisms of action and potential applications. Am J Clin Nut 2001; 74:41825.

31.Ostrowska J, Skrzydlewska E. The comparison of effect of catechins and green tea extract on oxidative modification of LDL in vitro. Adv Med Sci 2005; 51: 298303.

32.Rao YK, Fang SH, Tzeng YM. inhibitory effects of the flavonoids isolated from waltheria indica on the production of NO TNF-alpha and IL-12 in activated macrophages. Biol Pharm Bull 2005; 28:912-5.

33.Magalhaes AS, Silva BM, Pereira JA, Andrade PB, Valentao P, Carvalho M. Protective effect of quince (Cydonia oblonga Miller) fruit against oxidative hemolysis of human erythrocytes. Food Chem Toxicol 2009; 47:1372-7.

34.Silva BM, Andrade PB,Valentao P, Ferreres F, Seabra RM, Ferreira MA.
Quince (Cydonia oblonga Miller) fruit and jam antioxidant activity. J Agric Food Chem 2004; 52: 4705-12.

35.Kurin E, Atanasov AG, Donath O, Heiss EH, Dirsch VM, Nagy M. Synergy study of the inhibitory potential of red wine polyphenols on vascular smooth muscle cell proliferation. Planta Med 2012; 78: 772-8.

36.Costa RM, Magalhaes AS, Pereira JA, Andrade PB, Valentao P, Carvalho M, et al. Evaluation of free radical scavenging and antihemolytic activities of quince (Cydonia oblonga) leaf a comparative study with green tea (Camellia sinensis). Food Chem Toxicol 2009; 47:860-5.

37. Oliveira AP, Pereira JA, Andrade PB, Valentao P, Seabra RM, Silva BM. Phenolic profile of Cydonia oblonga Miller leaves. J Agric Food Chem 2007; 55: 792630.

38.Bodnar I, Gooz P, Okamura H, Toth BE, Vecsernye M, Halasz B, et al. Effect of neonatal treatment with monosodium glutamate on dopaminergic and L-DOPAergic neurons of the medial basal hypothalamus and on prolactin and $\mathrm{MSH}$ secretion of Rats. Brain Res Bull 2001; 55:767-74.

39.Nosseir NS, Mhm A, Ebaid HM. A histological and morphometric study of monosodium glutamate toxic effect on testicular structure and potentiality of recovery in adult albino Rats. J Biol 2012; 2:66-78.

40.Olney JW, Sharpe LG, Feigin RD. Glutamate induced brain damage in infant primates. J Neuropathol Exp Neurol 1972; 31:464-88.

41.Park $\mathrm{CH}$, Choi SH, Piao Y, Kim SH, Lee YJ, Kim HS, et al. Glutamate and aspartate impair memory retention and damage hypothalamic neurons in adult mice. Toxicol Lett 2000; 115:117-25. 


\title{
The Study of the Protective Effects of Quince (Cydonia Oblonga) Leaf Hydroalcoholic Extract on the Structural Alterations of Testicular Tissue Induced by Monosodium Glutamate in Adult Rats
}

\author{
Hamidi $\mathrm{J}^{I}$, Kianifard $D^{1 *}$, Vafaeisaiah $G^{I}$, Hazrati $R^{l}$
}

(Received: September 6, 2015

Accepted: November 28, 2015)

\begin{abstract}
Introduction: Monosodium glutamate is a food additive which acts as preservative or enhancer of palatability. Some studies show some adverse effects of this agent on reproductive system like as structural and functional alterations and reduction of fertility. According to various antioxidant properties of quince leaves and the cytotoxic effects of monosodium glutamate, the aim of this study was to evaluate the protective effects of quince leaf extract on testicular tissue alterations induced by monosodium glutamate.
\end{abstract}

Materials \& methods: 60 adult rats were divided into six groups: 1) control; 2) monosodium glutamate (30mg/kg i.p.); 3) monosodium glutamate $(60 \mathrm{mg} / \mathrm{kg}$ i.p.); 4) monosodium glutamate $(30 \mathrm{mg} / \mathrm{kg}$ i.p.) + quince leaf extract (500mg/kg p.o.); 5) monosodium glutamate $(60 \mathrm{mg} / \mathrm{kg}$ i.p. $)+$ quince leaf extract $(500 \mathrm{mg} / \mathrm{kg}$ p.o.) and 6) control + quince leaf extract $(500 \mathrm{mg} / \mathrm{kg}$ p.o.). At the end of eight weeks, histomorphometeric and spermatogenic evaluations were done on testicular samples.

Findings: The results showed that, administration of monosodium glutamate lead to structural and functional alteration of testicular tissue such as tubular atrophy and spermatogenic amendments while, use of quince leaf extract can reduce the revealed alterations.

Discussion \& conclusions: According to the findings, it is concluded that antioxidant herbs such as quince leaf, can be effective in reducing of structural alterations of testicular tissue induced by monosodium glutamate.

Kewords: Histomorphometry, Monosodium glutamate, Quince leaf extract, Rat, Testicular tissue

1. Dept of Basic Sciences, Faculty of Veterinary Medicine, University of Tabriz, Tabriz, Iran

*Correspondin author Email: davoudkianifard@gmail.com

Scientific Journal of Ilam University of Medical Sciences 